\title{
Developmental Changes in Gut Microbiota and Enzyme Activity Predict Obesity Risk in Rats Arising From Reduced Nests
}

\author{
Z. ŠEFČÍKOVÁ ${ }^{1}$, D. BUJŇÁKOVÁ ${ }^{1}$, L. RAČEK ${ }^{1}$, V. KMEŤ ${ }^{1}, \check{S ̆}^{\text {. MOZES̆ }}$ \\ ${ }^{1}$ Institute of Animal Physiology, Slovak Academy of Sciences, Košice, Slovak Republic
}

Received December 2, 2009

Accepted August 30, 2010

On-line November 29, 2010

\begin{abstract}
Summary
The aim of the study was to assess the impact of preweaning overnutrition upon the ontogeny of intestinal microbiota, alkaline phosphatase activity (AP) and parameters of growth and obesity in male Sprague-Dawley rats. We tested whether intestinal characteristics acquired in suckling pups could programme the development of enhanced fat deposition during normalized nutrition beyond weaning. Postnatal nutrition was manipulated by adjusting the number of pups in the nest to 4 (small litters - SL) and 10 (normal litters - NL). In the postweaning period both groups were fed with a standard diet. The jejunal and colonic Lactobacillus/Enterococcus (LAB) and the Bacteroides/Prevotella (BAC) were determined using the FISH technique, and the jejunal AP activity was assayed histochemically. At 15 and 20 days of age the SL pups became heavier, displayed increased adiposity accompanied by significantly higher $L A B$ and lower numbers of BAC and with higher AP activity in comparison with rats nursed in NL nests. These differences persisted to day 40 and withdrawal of the previous causal dietary influence did not prevent the postweaning fat accretion. These results reveal the significance of early nutritional imprint upon the gut microbial/functional development and allow better understanding of their involvement in the control of obesity.
\end{abstract}

\section{Key words}

Litter sizegut microbiota • Alkaline phosphatase activity • Obesity

\section{Corresponding author}

Š. Mozeš, Institute of Animal Physiology, Slovak Academy of Sciences, Šoltésovej 4, 040 01, Košice, Slovak Republic. Fax: +42155 7287842. E-mail: mozes@saske.sk

\section{Introduction}

It is generally agreed that the physiological processes of digestion may be an important factor affecting energy homeostasis, since the limitation of absorption and extraction of energy from the diet is one tool in the treatment of excessive weight and obesity (Aguirre et al. 2008, Heap and Cummings 2008). Numerous findings from human and animal studies have revealed that the quantity of two dominant divisions of gut bacteria, namely the Firmicutes and the Bacteroidetes, are closely related to the pathophysiology of obesity by altering the host's energy-harvesting efficiency. Accordingly, in obese animals and people a proportional increase in the numbers of Firmicutes and reduction of the Bacteroidetes in the gut has been demonstrated (Ley et al. 2005, Turnbaugh et al. 2006, Guo et al. 2008) whereas an opposite shift in the ratio of these microbiota occurs as obese humans lose weight on low-calory diets (Ley et al. 2006). On the other hand, evidence about such variations of intestinal microbiota in obese humans was contradictory. Regarding the Firmicutes and the Bacteroidetes, there were found no differences between obese and non obese individuals (Duncan et al. 2008) and even though in obese in comparison with normal weight peoples a significant abundance of Bacteroidetes has been documented (Zhang et al. 2009). Furthermore, although previous study of Ley et al. (2006) suggested on their distinct modifications during dietary induced weight loss, other results did not support such relations among these dominant gut bacteria, obesity and low-energy diet (Duncan et al. 2008).

While sedentary behavior and excessive calory 
intake are considered as important factors involved in increased incidence of worldwide obesity, the growing clinical and experimental evidence emphasizes the pivotal role of the postnatal dietary environment in programming sustained obesity risk with numerous confounding health complications in later life. It has been found that during development the higher milk energy and macronutrient intake in formula-fed as compared to breast-fed infants was associated with their greater growth, fat mass gain and BMI (Heinig et al. 1993, Ong et al. 2006). This contrasted with breast fed infants who gained weight and adiposity more slowly and displayed reduced risk of being overweight during childhood and adolescence (Gillman et al. 2001, Kalies et al. 2005, Mayer-Davis et al. 2006). Similarly, in experimental studies a close relationship between over-nutrition during key periods of lactation and programming of early life obesity has been confirmed. Due to excessive maternal milk fat and energy production and their increased intake, rats nursed in reduced litters (3-4 pups/nest) displayed increased adiposity (Fiorotto et al. 1991, Mozeš et al. 2004) accompanied by several metabolic and hormonal disturbances (Plagemann et al. 1999, Boullu-Ciocca et al. 2005). In addition, many of these syndrome X-like alterations (elevated triglycerides, free fatty acids, glucose, insulin) persisted into adult age, despite the rats changing to a standard laboratory diet after weaning (Plagemann et al. 1999, Boullu-Ciocca et al. 2005).

Recently, it has been shown that sustained exposure of rat pups to obesogenic diets (HF milk, fatrich solid diet) until day 40 of life was accompanied by permanently enhanced LAB (Lactobacillus/ Enterococcus), lowered numbers of BAC (Bacteroides/ Prevotella) and significantly higher alkaline phosphatase (AP) activity in the small intestine (Mozeš et al. 2008). Regarding intestinal function, increased AP activity has also been demonstrated in the brush-border of enterocytes in response to elevated dietary fat intake (Kaur et al. 2007, Mozeš et al. 2008, Šefčíková et al. 2008). These data provide evidence about the similar importance of early and late over-nutrition on maturation of the intestinal microbial/functional axis at the present time; however, no information is available as to how these acquired intestinal characteristics derived precisely from preweaning dietary influences may contribute to obesity after withdrawal of the previous causal dietary influence in subsequent period.

In this experiment, therefore, we examined the developmental diversity in the numbers of two microbial groups, i.e. Lactobacillus/Enterococcus, (members of the Firmicutes-LAB) and Bacteroides/Prevotella (Bacteroidetes-BAC) in the small and large intestine, as well as brush-border-bound jejunal alkaline phosphatase activity on days 15,20 and 40 in rats raised in small (4 pups/nest) or normal (10 pups/nest) litters and exposed to standard laboratory diet after weaning (day 21). This experimental design allowed us to specify whether the pre-existing gut changes could predict the energy balance control and persistence of obesity in later life.

\section{Methods}

Animals

The experiment was performed using the male offspring of Sprague-Dawley rat dams (Charles River Laboratories, Prague).The pregnant first-time mated rats (at 10 weeks of age) were individually housed in Plexiglas cages in a temperature-controlled environment of $22 \pm 2{ }^{\circ} \mathrm{C}, 12 \mathrm{~L}: 12 \mathrm{D}$ regime (light on 0600 to $1800 \mathrm{~h}$ ) and had free access to a standard laboratory diet (Laboratory diet M1, Řicmanice, Czech Republic; 13.4 $\mathrm{kJ} / \mathrm{g}$, with $26.3 \%$ energy as protein, $9.5 \%$ as fat and $64.2 \%$ as carbohydrate) and tap water.

At birth the litters of less than eight or more than twelve pups were excluded from the experiment. To induce early postnatal over-nutrition or normal nutrition, the litter size was adjusted to 4 pups (small litters, SL) and to 10 pups (normal litters, NL) within 24 hours of parturition. The weaned male rats (day 21) from these litters were individually housed under the same preweaning laboratory conditions (water, temperature, light-dark regime) and had free access to the standard diet.

To determine the growth and post-weaning feeding performance, the body weight in SL and NL pups was measured at birth and then every 5 days, and from day 21 until day 40 their food intake was recorded at 48 -h intervals. On days 15, 20 and 40 samples of adipose tissues and intestinal segments were taken after decapitation of the animals (between 0800 and 0900 hours). Bilateral whole fat pads were collected from the epididymal and perirenal regions. Lee's index of obesity (Lee 1929) was calculated from data $\sqrt[3]{ }$ body weight $(\mathrm{g})$ /nasoanal length $(\mathrm{cm})$. All animal work was in compliance with the rules of the Animal Ethics Committee of the Institute of Animal Physiology SAS, Košice, Slovak Republic. 


\section{Milk composition}

To investigate the relationship between litter size and milk composition, the milk samples of individual dams were collected on day 11 of lactation by a procedure described in detail previously (Mozeš et al. 1993). Milk fat content was determined by the crematocrit method of Lucas et al. (1978) expressed in $\mathrm{g} / 100 \mathrm{ml}$ milk using the formula given by Nagasawa et al. (1989). Milk protein concentration was analyzed using the method of Lowry et al. (1951).

\section{FISH analysis}

Fresh jejunal samples were sectioned into small pieces, cut longitudinally, washed thoroughly with sterile phosphate-buffered saline ( $\mathrm{pH} 7.4$ ), and the intestinal mucosa were removed for homogenization. Homogenized mucosa were fixed in $4 \%$ paraformaldehyde (Fluka, Buchs, Switzerland) overnight at $4{ }^{\circ} \mathrm{C}$ (Amann et al. 1995 ) and then stored in equal volumes of phosphatebuffered saline and $96 \%$ ethanol at $-20{ }^{\circ} \mathrm{C}$. A similar procedure was used in collection and preparation of luminal colonic samples.

The numbers of microbial communities in the proximal and distal intestine were assessed using the fluorescent in situ hybridization method with probes (VBC-Genomics, Vienna, Austria) Lab158 for Lactobacillus/Enterococcus sp. group $\mathrm{Cy} 3-5^{\prime}-$ GGTATTAGCA(C/T)CTGTTTCCA-3' (Harmsen et al. 1999), or Bac303 for Bacteroides/Prevotella group FITC-5'-CCAATGTGGGGGACCTT-3' (Manz et al. 1996). The hybridized samples were vacuum filtered onto $0.2-\mu \mathrm{m}$ polycarbonate membrane filters. A microscope (Olympus, Tokyo, Japan; BX 51) fitted with appropriate filters for $\mathrm{Cy} 3$ dye and FITC dye was used for enumeration of bacteria.

\section{Enzyme assays}

For enzyme assay small $(0.5 \mathrm{~cm})$ segments were immediately removed, the lumen was rinsed in distilled water and frozen in liquid nitrogen. Segments of the frozen tissue (middle part of the jejunum) were cut $(8 \mu \mathrm{m})$ in the cryostat at $-25^{\circ} \mathrm{C}$ and the tissue slices were transferred to glass slides and air dried.

The analysis of alkaline phosphatase activity was performed using a modified simultaneous azocoupling method (Lojda et al. 1979). The incubation medium contained $2.0 \mathrm{mmol} / 1$ naphthol AS-BI phosphate (Sigma, Deisenhofen, Germany), $0.8 \mathrm{mmol} / 1$ hexazotized new fuchsin (Serva, Heidelberg, Germany), and 0.05 mol/1 veronal acetate buffer. The sections were incubated at $37{ }^{\circ} \mathrm{C}$ for $10 \mathrm{~min}$ at $\mathrm{pH} 8.9$ (Mozeš et al. 1998). The histochemically-stained slides were illuminated with white light after filtering with a $520 \mathrm{~nm}$ monochromatic filter and visualized by image analysis. Quantification of the enzyme activity (pixel intensities) was carried out along the villus length in a whole section of at least four samples, and the mean values recorded were referred to one animal (Šefčíková et al. 2008).

\section{Statistical analysis}

All data are presented as means \pm S.E. and statistical significance was set at $\mathrm{P}<0.05$. The somatic and small intestinal responses to over-nutrition and normal nutrition were analyzed with two-way ANOVA, and Duncan's post hoc test was used to test the effects of age and litter size, and their interaction. For comparison of the post-weaning food intake and weight-gain differences between NL and SL groups, one-way ANOVA was used. All statistical analyses were performed using the software package Statistica 6.1 (StatSoftCR, Prague, Czech Republic).

\section{Results}

Litter size differences significantly influenced milk fat concentration of dams on postnatal day 11 . Comparing SL nursing dams with NL mothers, the mean values of milk fat concentration were $21.0 \pm 0.7$ vs. $16.4 \pm 0.8 \mathrm{~g} / 100 \mathrm{ml}$ respectively $(\mathrm{P}<0.001)$. In contrast to milk fat, no significant effect of litter size manipulation on milk protein concentration of SL and NL mothers was found $(8.5 \pm 0.3 \mathrm{vs} .8 .4 \pm 0.3 \mathrm{~g} / 100 \mathrm{ml})$.

There were no differences in birth weight between SL and NL pups (6.6 \pm 0.1 and $6.8 \pm 0.1)$. On days 15,20 and 40 the SL pups showed accelerated growth resulting in significantly higher mean body weight and in enhanced epididymal plus perirenal fat pads exceeding by about $67 \%, 39 \%$ and $48 \%$ the values of NL pups respectively (Table 1). In this context the SL rats displayed significantly increased Lee's index of obesity as compared to NL animals during the entire experiment.

The effect of litter size manipulation was accompanied by the early appearance of diversity in development of gut microbial composition and function, which persisted until day 40. Due to these changes the higher numbers of Lactobacillus/Enterococcus (LAB) were found in the jejunum and colon in SL rats. In addition, in rats arising from reduced nests in comparison 


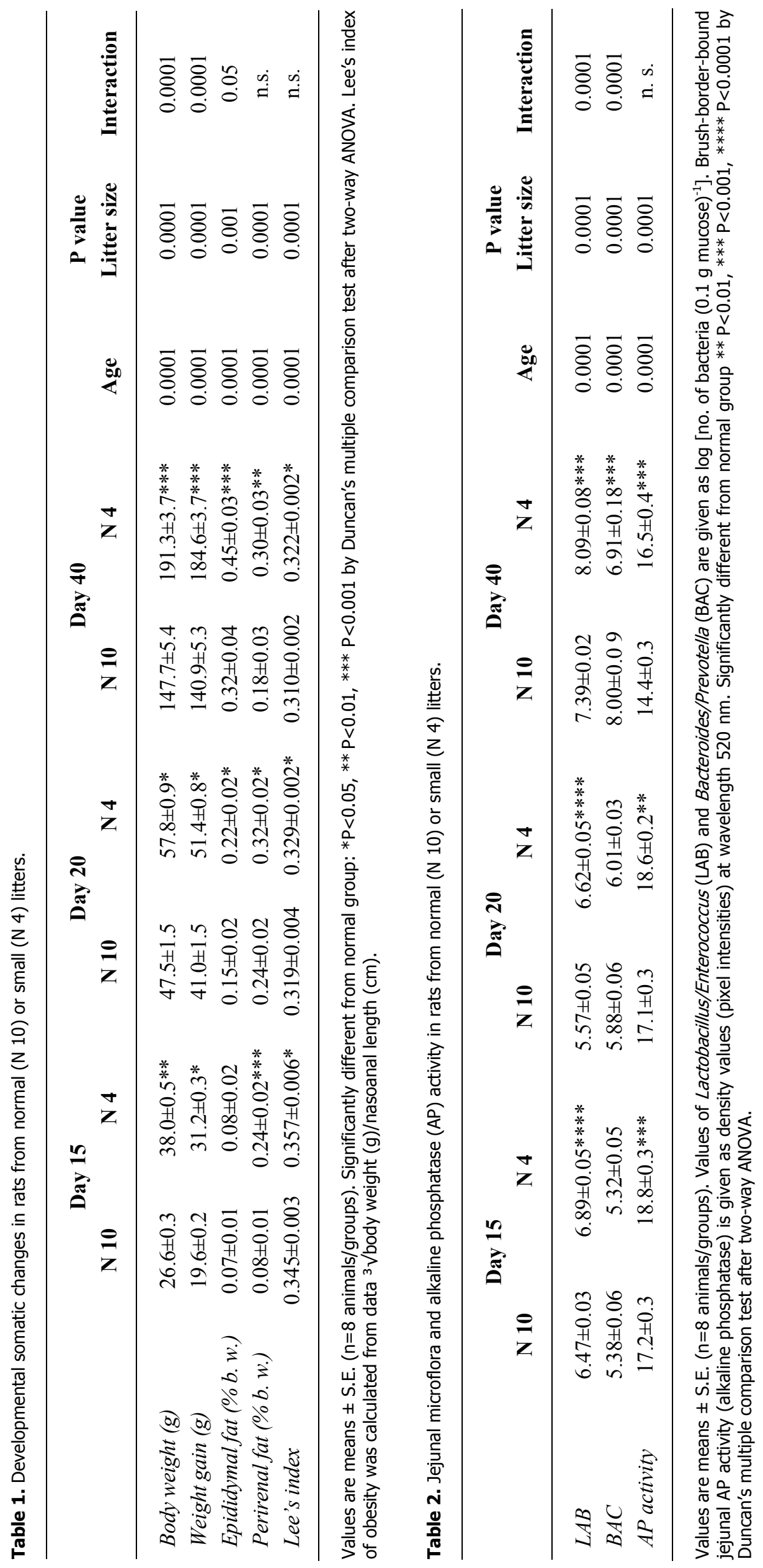


Table 3. Colonic microflora in rats from normal (N 10) or small (N 4) litters.

\begin{tabular}{cccccccc}
\hline & \multicolumn{2}{c}{ Day 20 } & \multicolumn{2}{c}{ Day 40 } & \multicolumn{2}{c}{ P value } \\
& $\mathbf{N}$ 10 & $\mathbf{N} 4$ & $\mathbf{N ~ 1 0}$ & $\mathbf{N ~ 4}$ & Age & Litter size & Interaction \\
\hline$L A B$ & $7.41 \pm 0.12$ & $8.34 \pm 0.04^{* * * * *}$ & $7.89 \pm 0.02$ & $9.08 \pm 0.03^{* * * *}$ & 0.0001 & 0.0001 & n.s. \\
$B A C$ & $7.13 \pm 0.06$ & $7.08 \pm 0.06$ & $8.24 \pm 0.09$ & $7.59 \pm 0.08^{* * *}$ & 0.0001 & 0.0001 & 0.001 \\
\hline
\end{tabular}

Values are means \pm S.E. ( $n=8$ animals/groups). Values of Lactobacillus/Enterococcus (LAB) and Bacteroides/Prevotella (BAC) are given as $\log$ [no. of bacteria $(0.1 \mathrm{~g} \text { content })^{-1}$ ]. Significantly different from normal group $* * * \mathrm{P}<0.001, * * * * \mathrm{P}<0.0001$ by Duncan's multiple comparison test after two-way ANOVA.

Table 4. Postweaning somatic and feeding parameters in rats from normal (N 10) or small (N 4) litters.

\begin{tabular}{lcccc}
\hline & $\begin{array}{c}\text { Weight gain }(\mathbf{g}) \\
\text { (day 21-40) }\end{array}$ & $\begin{array}{c}\text { Mean food } \\
\text { intake (g/day) }\end{array}$ & $\begin{array}{c}\text { Body fat } \\
(\mathbf{g})\end{array}$ & Food efficiency \\
\hline N 10 & $106.5 \pm 4.8$ & $11.8 \pm 0.38$ & $0.78 \pm 0.08$ & $2.11 \pm 0.04$ \\
$N 4$ & $131.8 \pm 3.5 * * *$ & $15.4 \pm 0.42^{* * *}$ & $1.47 \pm 0.10^{* * *}$ & $2.22 \pm 0.03 *$ \\
\hline
\end{tabular}

Values are means \pm S.E. ( $n=8$ animals/groups). Body fat represents weight of epididymal plus perirenal fat pads. Food efficiency is given as the food intake/body weight. Significantly different from normal group: *** $\mathrm{P}<0.001$ after one-way ANOVA.

with corresponding NL controls a higher LAB and lowered number of Bacteroides/Prevotella (BAC) were found despite their post-weaning transit on normal diet consumption (Table 2, Table 3). Consistently, the significant age and litter size, and age $\mathrm{x}$ litter size interaction in the jejunum ( $\mathrm{LAB} ; \mathrm{F}=19.1, \mathrm{BAC} ; \mathrm{F}=24.8$ ) as well as a significant effect of age and litter size on the LAB and BAC values in the colon was found by two-way ANOVA. Moreover, between these groups a different functional maturation of the small intestine was observed, i.e. in obese SL pups as compared with their corresponding controls a significant increase in jejunal alkaline phosphatase (AP) activity was recorded on day 15 , and these reciprocal differences persisted until day 40 (Table 2). Table 4 shows that the food intake, weight gain, food efficiency and body fat changes in SL and NL groups depended to some extent on their preweaning nutritional conditions. In the post-weaning period when SL and NL offspring were exposed to normal diet, their food intake (expressed as g/day) showed clear divergence, i.e. obese pups received significantly more food (about $23 \%$ ) and displayed higher weight gain (about $19 \%$ ) and their body fat accretion was consistently higher (about $48 \%$ ) than in leaner ones.

\section{Discussion}

Our results confirm the previous contention that early litter size manipulation was closely related to the significant long-lasting divergence in body weight between SL and NL rats (Mozeš et al. 2004, Davidowa et al. 2006). These changes might be attributed to higher dietary energy intake due to higher milk fat concentration leading to faster growth in SL pups. This assumption is also supported by the data showing positive correlation between milk fat and weight gains of pups throughout lactation period (Fiorotto et al. 1991, Mozeš et al. 1993). Because rat milk is rich in fat and proteins but poor in carbohydrates and the concentration of lactose and protein did not varied considerably in milk of SL vs. NL nursing mothers (Fiorotto et al. 1991, Del Prado et al. 1997, Mozeš et al. 2004) it seem to be clear, that the abundant energy intake of SL pups during the suckling period might be covered mainly from milk fat. Another question is, whether acquisition of somatic changes observed in SL pups might be derived also from further components of maternal/litter size interaction. Although it was revealed, that the production of milk is regulated by the number of pups in the nest and daily milk yield and fat milk concentration of rat dams suckling normal litters was substantially higher than in SL dams (Russell 1980, Fiorotto et al. 1991) this conclusion has to be considered with caution. Due to the higher energy and milk volume disposal observed in SL in comparison with NL pups (Fiorotto et al. 1991) it is likely that besides dietary fat, larger protein and carbohydrate intake might also be 
considered as a part of mechanism participating on their successive feeding performance. Another critical issue regarding of postnatal litter size reduction is their effect on the adjustment of subsequent milking response of the lactating rats. Due to the experimental paradigm of exactly standardized litters (10 pups/nest) applied in the present experiment this interaction might also be derived from previous maternal physiological performance during gestational period. In this context the observed increase of milk fat/energy content of SL dams should be theoretically attributable to adaptation process programming sufficient nutrition for higher number of pups.

Moreover, a similar experimental model has documented significant alterations in hormonal and neuronal systems contributing to negative feedback of satiety signals leading to persistence of excessive weight in juvenile and adult rats (Davidowa et al. 2006, Davidowa and Plagemann 2007). Therefore, early development of food intake regulation in the rat pups and different adjustment of its "set points" might be considered as critical for their concomitant somatic and feeding performance. This provides new insights into questions regarding control of energy balance during later periods of life when nutritional variability can induce a wide range of responses in feeding control systems. Accordingly, consumption of a high-fat diet is accompanied with increased energy intake, energy efficiency and body weight accretion, whereas compensatory adaptations in the metabolism of obese rats to prolonged caloric restriction results in enhanced food intake and more efficient weight regain during ad libitum consumption of a low-fat diet (MacLean et al. 2006, Jackman et al. 2008). In the light of our present results such metabolic flexibility might also be explained by early adjustment of positive energy balance as a consequence of acquired intestinal changes in SL as compared with NL animals.

Our results suggest that litter-size derived nutritional interventions during the suckling period lead to profound intestinal microbial and functional alterations, and that these changes are closely related with different modulation of energy balance and occurrence of susceptibility or resistance to obesity during development. In detail, we found that intake of exclusive milk diet (up to day 15) facilitated the growth of Lactobacillus/Enterococcus group (LAB) and AP activity in the jejunum of SL pups. These changes continued when these animals received milk and solid food (to day
20), as well as after their transit on standard laboratory diet from weaning to day 40 . In addition, microbial adaptation to altered post-weaning nutritional conditions was also accompanied by a higher $\mathrm{LAB}$ and a lower numbers of Bacteroides/Prevotella (BAC) in jejunum and colon in obese SL vs. lean NL pups. Along the same lines, several studies reveal a close relationship between gut microbial communities and regulation of energy balance also in adult obese animals. It has been shown that the intestinal microbiota promote more efficient absorption of monosaccharides from the gut lumen and de novo hepatic lipogenesis (Bäckhed et al. 2004, Cani et al. 2007a). Their presence and composition in the gut played an important role in overall host metabolism/energy deposition and was considered as a part of mechanism that positively influenced the obesity development in mice consuming a high-fat diet (Bäckhed et al. 2007, Cani et al. 2007b). Moreover, the contribution of two dominant gut bacterial divisions as a putative factor of excess caloric yield is highlighted in genetically-obese mice and pigs. In obese animals consuming standard diet (from weaning to adult age), no significant differences in food/energy intake in comparison with lean controls has been documented (Ley et al. 2005, Guo et al. 2008), and despite this nutritional benefit its expression of obesity was not diminished. The latest obesity related host- microbial links were also consistent with the observed abundance of Firmicutes and decrease of Bacteroidetes in the distal gut of these animals. Since the intestinal tract has different metabolic function i.e. its key physiological role is closely related to digestion and absorption of carbohydrates proteins and fats in the small intestine and short-chain fatty acids in the large intestine (DiBaise et al. 2008), our data monitoring diet-related changes in bacterial communities within the jejunum and colon also extend the current knowledge about their distinct role during the development of obesity.

Regarding the observed relationship between microbial diversity of LAB (members of the Firmicutes), BAC and obesity status, our present results are in agreement with significant findings in other studies based on measurement of two major groups of gut bacteria, i.e. the Firmicutes and the Bacteroidetes. These studies have shown that obese animals and humans have a relative abundance of Firmicutes in comparison to Bacteroidetes, and increased F/B ratio within caecal and colon microflora (Ley et al. 2005, 2006, Armougom and Raoult 2008, Guo et al. 2008). On the other hand, other results 
concerning the impact of these bacterial groups in humans were inconclusive. In fecal samples of adult obese subjects no significant differences in Firmicutes but significantly lower proportion of Bacteroidetes was revealed (Turnbaugh et al. 2009). Moreover, it has also been reported that the proportions of these groups in fecal bacteria (using the FISH technique) did not differ between obese and lean subjects (Duncan et al. 2008). Nevertheless, the authors do not rule out the possibility that more detailed analysis - particularly of differences in eating habits or host physiology - will reveal the cause of such inconsistency. From this point of view, our findings provide some perspective on how the excess energy intake during early life might be associated with altered intestinal characteristics during the development of obesity. However, whether these acquired changes of gut microbiota would be a key indicator encoding the cause of adverse and/or positive consequences of the future dietary manipulations on adiposity, body weight and feeding performance remains not fully elucidated. Such a possibility is partially revealed by persisting effect of early nutritional experiences on somatic and microbial profile of SL rats accompanied with hyperphagia despite their transit to normalized feeding conditions in subsequent post-weaning period. Moreover, by using a similar experimental paradigm a similar feeding pattern was demonstrated in SL rats until adulthood (BoulluCiocca et al. 2005, Davidowa and Plagemann 2007) indicating that these sustained changes in food ingestion might be derived from their previous adjustment.

In summary, our results in this experimental model of postnatal over-nutrition produce additional evidence for the idea that the dietary environment during the postnatal period might be considered as an important factor affecting the ontogeny of intestinal microbial communities. Moreover, the present data suggest that early interference with these gut microbial and functional parameters may predict higher body weight and adiposity in later life. It could be speculated that some kind of alteration in the intestinal maturation may have an important function in adjustment of future eating habits and different regulation of energy disposal in obese humans. This assumption seems to be confirmed by the clinically meaningful effect of altered energy/ macronutrient intake in weight-loss programs where reduced calory intake itself causes weight loss in overweight subjects (Shai et al. 2008, Sacks et al. 2009). However, the question whether differences in efficiency of diets based on ranges of fat, protein and carbohydrate content might be derived from other interrelated metabolic adjustments, including a favorable shift in fuel utilization, remains to be answered. As the causes of human obesity are multifactorial, involving genetic, hormonal, dietary and environmental factors, comprehensive information about the ontogeny of gut microbiota in relation to early nutritional background might be important for better understanding of obesity development and expression of susceptibility or resistance to diet-induced obesity in later life. This knowledge could be a useful tool for future pharmacological and dietary strategies in prevention and treatment of obesity in childhood and adult life.

\section{Conflict of Interest}

There is no conflict of interest.

\section{Acknowledgements}

We thank Andrew Billingham for his revision of the English in this article. This work was supported by VEGA grant 2/0014/08 of the Slovak Academy of Sciences.

\section{References}

AGUIRRE V, STYLOPOULOS N, GRINBAUM R, KAPLAN LM: An endoluminal sleeve induces substantial weight loss and normalizes glucose homeostasis in rats with diet-induced obesity. Obesity (Silver Spring) 16: 2585 2592, 2008.

AMANN RI, LUDWIG W, SCHLEIFER KH: Phylogenetic identification and in situ detection of individual microbial cells without cultivation. Microbiol Rev 59: 143-169, 1995.

ARMOUGOM F, RAOULT D: Use of pyrosequencing and DNA barcodes to monitor variations in Firmicutes and Bacteroidetes communities in the gut microbiota of obese humans. BMC Genomics 9: 576, 2008.

BÄCKHED F, DING H, WANG T, HOOPER LV, KOH GY, NAGY A, SEMENKOVICH CF, GORDON JI: The gut microbiota as an environmental factor that regulates fat storage. Proc Natl Acad Sci USA 101: 15718-15723, 2004. 
BÄCKHED F, MANCHESTER JK, SEMENKOVICH CF, GORDON JI: Mechanisms underlying the resistance to diet-induced obesity in germ-free mice. Proc Natl Acad Sci USA 104: 979-984, 2007.

BOULLU-CIOCCA S, DUTOUR A, GUILLAUME V, ACHARD V, OLIVER C, GRINO M: Postnatal diet-induced obesity in rats upregulates systemic and adipose tissue glucocorticoid metabolism during development and in adulthood: its relationship with the metabolic syndrome. Diabetes 54: 197-203, 2005.

CANI PD, AMAR J, IGLESIAS MA, POGGI M, KNAUF C, BASTELICA D, NEYRINCK AM, FAVA F, TUOHY KM, CHABO C, WAGET A, DELMÉE E, COUSIN B, SULPICE T, CHAMONTIN B, FERRIÈRES J, TANTI JF, GIBSON GR, CASTEILLA L, DELZENNE NM, ALESSI MC, BURCELIN R: Metabolic endotoxemia initiates obesity and insulin resistance. Diabetes 56: 1761-1772, 2007a.

CANI PD, NEYRINCK AM, FAVA F, KNAUF C, BURCELIN RG, TUOHY KM, GIBSON GR, DELZENNE NM: Selective increases of bifidobacteria in gut microflora improve high-fat-diet-induced diabetes in mice through a mechanism associated with endotoxaemia. Diabetologia 50: 2374-2383, $2007 \mathrm{~b}$.

DAVIDOWA H, ZISKA T, PLAGEMANN A: GABAA receptor antagonists prevent abnormalities in leptin, insulin and amylin actions on paraventricular hypothalamic neurons of overweight rats. Eur $J$ Neurosci 23: 12481254, 2006.

DAVIDOWA H, PLAGEMANN A: Insulin resistance of hypothalamic arcuate neurons in neonatally overfed rats. Neuroreport 18: 521-524, 2007.

DEL PRADO M, DELGADO G, VILLALPANDO S: Maternal lipid intake during pregnancyand lactation alters milk composition and production and litter growth in rats. J Nutr 127: 458-462, 1997.

DIBAISE JK, ZHANG H, CROWELL MD, KRAJMALNIK-BROWN R, DECKER GA, RITTMANN BE: Gut microbiota and its possible relationship with obesity. Mayo Clin Proc 83: 460-469, 2008.

DUNCAN SH, LOBLEY GE, HOLTROP G, INCE J, JOHNSTONE AM, LOUIS P, FLINT HJ: Human colonic microbiota associated with diet, obesity and weight loss. Int J Obes 32: 1720-1724, 2008.

FIOROTTO ML, BURRIN DG, PEREZ M, REEDS PJ: Intake and use of milk nutrients by rat pups suckled in small, medium, or large litters. Am J Physiol 260: R1104-R1113, 1991.

GILLMAN MW, RIFAS-SHIMAN SL, CAMARGO CA JR, BERKEY CS, FRAZIER AL, ROCKETT HR, FIELD AE, COLDITZ GA: Risk of overweight among adolescents who were breastfed as infants. JAMA 285: 24612467, 2001.

GUO X, XIA X, TANG R, WANG K: Real-time PCR quantification of the predominant bacterial divisions in the distal gut of Meishan and Landrace pigs. Anaerobe 14: 224-228, 2008.

HARMSEN HJM, ELFFERICH P, SCHUT F, WELLING GW: A 16S rRNA-targeted probe for detection of lactobacilli and enterococci in faecal samples by fluorescent in situ hybridization. Microb Ecol Health Dis 11: 3-12, 1999.

HEAP AJ, CUMMINGS DE: A novel weight-reducing operation: lateral subtotal gastrectomy with silastic ring plus small bowel reduction with omentectomy. Obes Surg 18: 819-828, 2008.

HEINIG MJ, NOMMSEN LA, PEERSON JM, LONNERDAL B, DEWEY KG: Energy and protein intakes of breastfed and formula-fed infants during the first year of life and their association with growth velocity: the DARLING Study. Am J Clin Nutr 58: 152-161, 1993.

JACKMAN MR, STEIG A, HIGGINS JA, JOHNSON GC, FLEMING-ELDER BK, BESSESEN DH, MACLEAN PS: Weight regain after sustained weight reduction is accompanied by suppressed oxidation of dietary fat and adipocyte hyperplasia. Am J Physiol 294: R1117-R1129, 2008.

KALIES H, HEINRICH J, BORTE N, SCHAAF B, VON BERG A, VON KRIES R, WICHMANN HE, BOLTE G; LISA STUDY GROUP: The effect of breastfeeding on weight gain in infants: results of a birth cohort study. Eur J Med Res 10: 36-42, 2005.

KAUR J, MADAN S, HAMID A, SINGLA A, MAHMOOD A: Intestinal alkalinephosphatase secretion in oil-fed rats. Dig Dis Sci 52: 665-670, 2007.

LEE MO: Determination of the surface area of the white rat with application to the expressionof metabolic results. $A m J$ Physiol 89: 24-33, 1929.

LEY RE, BÄCKHED F, TURNBAUGH P, LOZUPONE CA, KNIGHT RD, GORDON JI: Obesity alters gut microbial ecology. Proc Natl Acad Sci USA 102: 11070-11075, 2005. 
LEY RE, TURNBAUGH PJ, KLEIN S, GORDON JI: Microbial ecology: human gut microbes associated with obesity. Nature 444: 1022-1023, 2006.

LOJDA Z, GOSSRAU R, SCHIBLER TH: Enzyme Histochemistry. Springer, Berlin, 1979, pp 59-70.

LOWRY OH, ROSENBROUGH NJ, FARR AL, RANDALL RR: Protein measurement with the Folin phenol reagent. J Biol Chem 193: 265-275, 1951.

LUCAS A, GIBBS JH, LYSTER RL, BAUM JD: Crematocrit: simple clinical technique for estimating fat concentration and energy value of human milk. Brit Med J 1: 1018-1020, 1978.

MACLEAN PS, HIGGINS JA, JACKMAN MR, JOHNSON GC, FLEMING-ELDER BK, WYATT HR, MELANSON EL, HILL JO: Peripheral metabolic responses to prolonged weight reduction that promote rapid, efficient regain in obesity-prone rats. Am J Physiol 290: R1577-R1588, 2006.

MANZ W, AMANN R, LUDWIG W, VANCANNEYT M, SCHLEIFER KH: Application of a suite of 16S rRNAspecific oligonucleotide probes designed to investigate bacteria of the phylum cytophaga-flavobacterbacteroides in the natural environment. Microbiology 142: 1097-1106, 1996.

MAYER-DAVIS EJ, RIFAS-SHIMAN SL, ZHOU L, HU FB, COLDITZ GA, GILLMAN MW: Breast-feeding and risk for childhood obesity: does maternal diabetes or obesity status matter? Diabetes Care 29: 2231-2237, 2006.

MOZEŠ Š, KUCHÁR S, RYBOŠOVÁ Z, NOVÁKOVÁ V: Milk fat concentration and growth of rat pups. Physiol Res 42: 29-33, 1993.

MOZEŠ Š, LENHARDT L', MARTINKOVÁ A: A quantitative histochemical study of alkaline phosphatase activity in isolated rat duodenal epithelial cells. Histochem J 30: 1-7, 1998.

MOZEŠ Š, ŠEFČÍKOVÁ Z, LENHARDT L', RAČEK L': Obesity and changes of alkaline phosphatase activity in the small intestine of 40- and 80-day-old rats subjected to early postnatal overfeeding or monosodium glutamate. Physiol Res 53: 177-186, 2004.

MOZEŠ Š, BUJŇÁKOVÁ D, ŠEFČÍKOVÁ Z, KMEŤ V: Developmental changes of gut microflora and enzyme activity in rat pups exposed to fat-rich diet. Obesity (Silver Spring) 16: 2610-2615, 2008.

NAGASAWA H, NAITO T, KATAOKA K: Relationship between milk composition and pup's growth in mice. Proc Soc Exp Biol Med 191: 78-81, 1989.

ONG KK, EMMETT PM, NOBLE S, NESS A, DUNGER DB, ALSPAC STUDY TEAM: Dietary energy intake at the age of 4 months predicts postnatal weight gain and childhood body mass index. Pediatrics 117: e503-e508, 2006.

PLAGEMANN A, HARDER T, RAKE A, VOITS M, FINK H, ROHDE W, DÖRNER G: Perinatal elevation of hypothalamic insulin, acquired malformation of hypothalamic galaninergic neurons, and syndrome x-like alterations in adulthood of neonatally overfed rats. Brain Res 836: 146-155, 1999.

RUSSELL JA: Milk yield, suckling behaviour and milk ejection in the lactating rat nursinglitters of different sizes. J Physiol 303: 403-415,1980.

SACKS FM, BRAY GA, CAREY VJ, SMITH SR, RYAN DH, ANTON SD, MCMANUS K, CHAMPAGNE CM, BISHOP LM, LARANJO N, LEBOFF MS, ROOD JC, DE JONGE L, GREENWAY FL, LORIA CM, OBARZANEK E, WILLIAMSON DA: Comparison of weight-loss diets with different compositions of fat, protein, and carbohydrates. N Engl J Med 360: 859-873, 2009.

SHAI I, SCHWARZFUCHS D, HENKIN Y, SHAHAR DR, WITKOW S, GREENBERG I, GOLAN R, FRASER D, BOLOTIN A, VARDI H, TANGI-ROZENTAL O, ZUK-RAMOT R, SARUSI B, BRICKNER D, SCHWARTZ Z, SHEINER E, MARKO R, KATORZA E, THIERY J, FIEDLER GM, BLÜHER M, STUMVOLL M, STAMPFER MJ; DIETARY INTERVENTION RANDOMIZED CONTROLLED TRIAL (DIRECT) GROUP: Weight loss with a low-carbohydrate, Mediterranean, or low-fat diet. $N$ Engl J Med 359: 229-241, 2008.

ŠEFČÍKOVÁ Z, HÁJEK T, LENHARDT L', RAČEK L, MOZEŠ Š: Different functional responsibility of the small intestine to high-fat/high-energy diet determined the expression of obesity-prone and obesity-resistant phenotypes in rats. Physiol Res 57: 467-474, 2008.

TURNBAUGH PJ, LEY RE, MAHOWALD MA, MAGRINI V, MARDIS ER, GORDON JI: An obesity-associated gut microbiome with increased capacity for energy harvest. Nature 444: 1027-1031, 2006. 
TURNBAUGH PJ, HAMADY M, YATSUNENKO T, CANTAREL BL, DUNCAN A, LEYRE, SOGIN ML, JONES WJ, ROE BA, AFFOURTIT JP, EGHOLM M, HENRISSAT B, HEATH AC, KNIGHT R, GORDON JI: A core gut microbiome in obese and lean twins. Nature 457: 480-484, 2009.

ZHANG H, DIBAISE JK, ZUCCOLO A, KUDRNA D, BRAIDOTTI M, YU Y, PARAMESWARAN P, CROWELL MD, WING R, RITTMANN BE, KRAJMALNIK-BROWN R: Human gut microbiota in obesity and after gastric bypass. Proc Natl Acad Sci USA 106: 2365-2370, 2009. 